\title{
Meningkatkan Hasil Belajar Teks Narrative melalui Metode Role Playing Pada Siswa SMP Islam Banda Aceh
}

\author{
Mariani \\ Guru SMP Islam Banda Aceh \\ Email : mariani82@gmail.com \\ DOI : 10.32672/jsa.v7i5.1528
}

\begin{abstract}
ABSTRAK
Penelitian ini bertujuan untuk meningkatkan hasil belajar siswa pada mata pelajaran Bahasa Inggris pembahasan teks narrative Metode penelitian yang digunakan adalah penelitian tindakan kelas (PTK) yang terdiri atas dua siklus, setiap siklus dilaksanakan 3 kali pertemuan dan pada pertemuan ketiga setiap siklus dilaksanakan pengukuran hasil belajar melalui tes . Yang menjadi subyek penelitian tindakan kelas ini adalah siswa kelas IX SMP Islam Banda Aceh tahun pelajaran 2017/2018 sebanyak 31 siswa. Analisis data menggunakan teknik analisis diskriptif komparatif dengan membandingkan kondisi awal dengan hasil-hasil yang dicapai pada setiap siklus, dan analisis deskriptif kualitatif hasil observasi dengan membandingkan hasil observasi dan refleksi pada siklus I dan siklus 2. Dari hasil tes yang dilakukan setiap siklus terjadi peningkatan hasil belajar siswa secara signifikan, sehingga dapat diambil kesimpulan bahwa dengan menggunakan metode role playing dapat meningkatkan ketuntasan belajar siswa. Yaitu sebanyak $42 \%$ yaitu dari kondisi awal 35\% (hasil tes pra siklus) menjadi 77\% (hasil tes siklus terakhir) terhadap siswa SMP Islam Banda Aceh. Dengan demikian penelitian ini telah dianggap berhasil dan dapat dijadikan referansi pagi guru lain guna meningkatkan prestasi belajar siswa.
\end{abstract}

Kata Kunci : Role Playing, teks narrative, SMP Islam

\section{PENDAHULUAN}

Keberhasilan proses belajar mengajar sangat ditentukan oleh kemampuan guru dalam memerankan sebagai pemimpin, fasilitator, dinamisator dan sekaligus sebagai pembantu. Dalam kutipan Menteri Pendidikan No. 84/1993 antara lain disebutkan bahwa wewenang guru adalah memilih dan menentukan metode kerja untuk mencapai hasil pendidikan yang optimal sesuai dengan kode etik guru. Seorang guru harus mampu menetukan strategi atau cara sehingga memiliki keyakinan dalam mendapatkan tujuan khusus dan tujuan umum proses belajar. Dari hasil pemantauan pelaksanaan kegiatan belajar mengajar banyak permasalahan-permasalahan pada pembelajaran yang sering muncul antara lain kekurangan minat balajar, kurangnya minat belajar, siswa tidak dapat menguasai mata pelajaran apa yang kita harapkan tidak akan tercapai.

Berdasarkan hasil observasi awal yang penulis dapatkan pada siswa kelas IX di SMP Islam Banda Aceh adalah kesulitan belajar di dalam mempelajari pelajaran Bahasa Inggris, yaitu kurangnya memahami bagaimana cara membaca teks narative, dan bisa di simpulkan bahwa pembelajaran yang dilaksanakan pada siswa belum maksimal, sehingga 
hasil belajar siswa tidak sesuai dengan yang diharapkan. Dari pengamatan penulis siswa belum serius mengikuti pembelajaran dari guru, guru juga belum menggunakan cara-cara dan metode yang tepat, guru juga belum menggunakan strategi sesuai dengan indikator pembelajaran. Pembelajaran seperti itu mengakibatkan hasil belajar siswa rendah, rendahnya hasil belajar terindikasi dari siswa yang mencapai ketuntasan belajar diperkirakan sekitar $40 \%$ dan $60 \%$ siswa belum tuntas belajar.

Dari pengamatan penulis siswa belum serius mengikuti pembelajaran dari guru, guru juga belum menggunakan cara-cara dan metode yang tepat, guru juga belum menggunakan strategi yang sesuai dengan indikator pembelajaran, pembelajaran seperti itu berakibat hasil belajarnya rendah, rendahnya hasil belajar terindikasi bahwa nilai yang diperoleh siswa juga masih rendah. Siswa yang mencapai ketuntasan belajar diperkirakan sekitar $40 \%$, sehubungan dengan hal tersebut diatas, penulis memperhatikan siswa yang tuntas belajar hanya lebih kurang $40 \%$ sedangkan $60 \%$ siswa belum tuntas belajar. Faktor utama yang menjadi permasalahan adalah kurangnya kreatifitas guru menggunakan metode dan strategi guna pencapaian indikator dan kompetensi dasar yang sesuai dengan yang diharapkan. Pelaksanaan penelitian tindakan kelas ini merupakan upaya penulis untuk meningkatkan hasil belajar siswa sehingga ketuntasan hasil belajar siswa dapat meningkat. Peningkatan ketuntasan siswa diharapkan lebih baik dari awal ketuntasan belajar siswa $40 \%$ meningkat menjadi $70 \%$.

Belajar bahasa pada hakikatnya adalah belajar komunikasi. Oleh karena itu, pembelajaran bahasa diarahkan untuk meningkatkan kemampuan pebelajar dalam berkomunikasi, baik lisan maupun tulisan. Hal ini relevan dengan kurikulum 2004 belajar bahasa diarahkan ke dalam empat subaspek, yaitu membaca, berbicara, menyimak, dan mendengarkan. Wibowo (2001:3) Bahasa adalah sistem simbol bunyi yang bermakna dan berartikulasi (dihasilkan oleh alat ucap) yang bersifat arbitrer dan konvensional, yang dipakai sebagai alat berkomunikasi oleh sekelompok manusia untuk melahirkan perasaan dan pikiran. Djarjowidjojo, (2003: 16) memberikan definisi bahasa adalah suatu sistem simbol lisan yang arbitrer yang dipakai oleh anggota suatu masyarakat bahasa untuk berkomunikasi dan berinteraksi antar sesamanya, berlandaskan pada budaya yang mereka miliki bersama. Pendapat lain dari Kridalaksana (2008: 24) mendefinisikan bahasa adalah sistem lambang bunyi yang arbitrer yang digunakan oleh suatu anggota masyarakat untuk bekerja sama, berinteraksi dan untuk mengidentifikasikan diri.

Dalam kurikulum 2004 untuk SMP, disebutkan bahwa tujuan pemelajaran Bahasa Inggris secara umum meliputi: 1) siswa menghargai Bahasa Inggris sebagai bahasa persatuan (Internasional) dan bahasa negara; 2) siswa memahami Bahasa Inggris dari bentuk, makna, dan fungsi, serta menggunakannya dengan tepat dan kreatif untuk bermacam-macam tujuan, keperluan, dan keadaan; 3) siswa memiliki kemampuan Bahasa Inggris untuk meningkatkan kemampuan intelektual, kematangan emosional,dan kematangan sosial; 4) siswa memiliki disiplin dalam berpikir dan berbahasa (berbicara dan menulis); 5)siswa mampu menikmati dan memanfaatkan bahasa inggris untuk mengembangkan kepribadian, memperluas wawasan kehidupan, serta untuk meningkatkan pengetahuan dan kemampuan berbahasa. 
Mariani

Untuk mencapai tujuan tersebut di atas, pembelajaran bahasa Inggris harus mengetahui prinsip-prinsip belajar bahasa yang kemudian diwujudkan dalam kegiatan pembelajarannya, serta menjadikan aspek-aspek tersebut sebagai petunjuk dalam kegiatan pembelajarannya. Prinsip-prinsip belajar bahasa dapat disarikan sebagai berikut, siswa akan belajar bahasa dengan baik bila: 1) diperlakukan sebagai individu yang memiliki kebutuhan dan minat; 2) diberi kesempatan berparstisipasi dalam penggunaan bahasa secara komunikatif dalam berbagai macam aktivitas; 3) bila ia secara sengaja memfokuskan pembelajarannya kepada bentuk, keterampilan, dan strategi untuk mendukung proses pemerolehan bahasa; 4) ia disebarkan dalam data sosiokultural dan pengalaman langsung dengan budaya menjadi bagian dari bahasa sasaran; 5) jika menyadari akan peran dan hakikat bahasa dan budaya; 6) jika diberi umpan balik yang tepat menyangkut kemajuan mereka; 7) jika diberi kesempatan untuk mengatur pembelajaran mereka sendiri.

Sabri (2005:52) Metode pembelajaran adalah cara-cara atau teknik penyajian bahan pelajaran yang akan digunakan oleh guru pada saat pembelajaran, baik secara individual atau secara kelompok. Pada penelitian ini metode yang akan dibahas yakni metode bermain peran. Metode bermain peran juga biasa disebut dengan Role Playing. Pengertian bermain peran adalah salah satu bentuk pembelajaran, dimana peserta didik ikut terlibat aktif memainkan peran-peran tertentu. Menurut Komalasari role playing adalah suatu metode penguasaan bahan-bahan pelajaran melalui pengembangan imajinasi dan penghayatan siswa, Komalasari (2011:80). Dapat disimpulkan bahwa Role Playing merupakan bagian dari kegiatan simulasi. Situasi keseluruhan disimulasikan dalam kelas, dan para pembelajarnya memerankan peran dalam situasi keseluruhan tersebut. Menurut Harmer (2007: 352), dalam Role Playing, peran dan bagaimana peran dilaksanakan telah dipersiapkan dan ditentukan.

Amato (2003:214) menambahkan bahwa melalui kegiatan role playing pembelajar dapat menggali kemampuan dirinya, memiliki rasa empati pada orang lain, dan menggunakan pengalaman pribadinya agar dapat melakukan tindakan-tindakan yang hebat. Role playing dapat meningkatkan kemampuan pembelajar memproduksi bahasa target, menguasai aspek-aspek komunikasi nonverbal, meningkatkan kemampuan kerja sama antar pembelajar, dan meningkatkan kecakapan ranah afektif. Shaftel \& Shaftel (dalam Amato, 2003: 223) merancang suatu tahapan yang terdiri atas sebelas tahapan dalam melaksanakan kegiatan Role Playing, yaitu: (1) memperkenalkan topik kegiatan; (2) mendorong ketertarikan pebelajar, (3) menyajikan kosakata baru, (4) membaca cerita yang secara jelas menuju pada suatu permasalahan, (5) menghentikan cerita pada saat klimaks, (6) mendiskusikan dilema yang ada, (7) memilih pembelajar memainkan peran, (8) mempersiapkan pembelajar yang lain untuk menyimak dan selanjutnya memberikan nasihat, (9) memerankan cerita yang tersisa, (10) mendiskusikan jalan keluar alternatif yang berhubungan dengan permasalahan, dan (11) memerankan kembali cerita menggunakan strategi baru bila diperlukan. Melalui metode pembelajaran role playing diharapkan dapat meningkatkan hasil belajar bahasa Inggris pembahsan teks arrative. 
Serambi Akademica

Jurnal Pendidikan, Sains, dan Humaniora
Vol. 7, No. 4,

Oktober 2019
pISSN 2337-8085

eISSN 2657- 0998

\section{METODE PENELITIAN}

Penelitian tindakan kelas ini penulis laksanakan di SMP Islam Banda Aceh tahun ajaran 2017/2018. Penelitian ini laksanakan selama dalam kurun waktu 3 bulan sejak Maret sampai dengan Juni 2017semester II tahun pembelajaran 2017/2018. Subyek penelitian tindakan kelas ini adalah siswa-siswi kelas IX SMP Islam Banda Aceh sebanyak 31orang yang terdiri dari 17 siswa laki-laki dan 14 siswa perempuan. Sumber data penelitian tindakan kelas ini diperoleh dari siswa kelas IX SMP Islam Banda Aceh, guru atau teman sejawat sebagai kolabotor atau observer dalam melaksanakan penelitian ini dan dari pihak lain yang terkait (kepala sekolah, guru kelas).

\section{HASIL PENELITIAN DAN PEMBAHASAN Pelaksanaan Pra siklus}

Pada pelaksanaan pembelajaran sebelum penelitian berjalan atau prasiklus pembelajaran pada mata pelajaran pendidikan Bahasa Inggris masih rendah, rendahnya hasil belajar dapat berdampak pada rendahnya nilai yang dimiliki siswa sehingga berpengaruh pada pencapaian KKM. Hasil tes siswa diketahui bahwa siswa yang mencapai ketuntasan belajar diperkirakan sekitar 40\%, sedangkan 60\% siswa lagi belum mencapai ketuntasan dalam belajar. Hasil tes pra siklus dapat dilihat pada tabel di bawah ini.

Tabel 1. Rekapan Hasil Belajar Siswa Pra Siklu

\begin{tabular}{|c|c|c|c|c|c|}
\hline No & Hasil (angka) & Hasil (huruf) & Arti Lambang & Jumlah Siswa & Persentase (\%) \\
\hline 1 & $86-100$ & A & Sangat baik & 0 & 0 \\
\hline 2 & $71-85$ & B & Baik & 0 & 0 \\
\hline 3 & $56-70$ & C & Cukup & 13 & 42 \\
\hline 4 & $41-55$ & D & Kurang & 18 & 58 \\
\hline 5 & $<40$ & E & Sangat kurang & 0 & 0 \\
\hline \multicolumn{7}{|c|}{ Jumlah } & 31 & $100 \%$ \\
\hline
\end{tabular}

Berdasarkan tabel di atas menunjukkan bahwa yang jumlah yang mendapat nilai sangat baik (86-100) adalah tidak ada (0\%), yang mendapat nilai baik (75-85) tidak ada $(0 \%)$, yang mendapat nilai cukup (56-70) berjumlah 13 orang $(42 \%)$, yang mendapat nilai kurang (41-55) berjumlah 18 orang (58\%) dan siswa yang mendapat nilai sangat kurang $(<40)$ tidak ada $(0 \%)$.

Tabel 2. Ketuntasan Belajar Siswa Pra Siklus

\begin{tabular}{|c|c|c|c|}
\hline \multirow{2}{*}{ No } & \multirow{2}{*}{ Ketuntasan } & \multicolumn{2}{|c|}{ KKM 68 } \\
\cline { 3 - 4 } & & Jumlah & Persentase (\%) \\
\hline 1 & Tuntas & 11 & 35 \\
\hline 2 & Tidak tuntas & 20 & 65 \\
\hline \multicolumn{2}{|c|}{ Jumlah } & 31 & 100 \\
\hline
\end{tabular}

Berdasarkan tabel 2 di atas penulis dapat didiskripsikan bahwa persentase ketuntasan belajar siswa masih sangat jauh dari KKM minimal yang direncanakan yaitu 
Mariani

siswa yang tuntas belajar berjumlah 11 orang atau $35 \%$ dari 31 jumlah siswa keseluruhan sedangkan yang tidak tuntas berjumlah 20 siswa atau $61 \%$.

Tabel 3. Rata-rata Hasil Tes Pra siklus

\begin{tabular}{|l|l|c|}
\hline No & \multicolumn{1}{|c|}{ Keterangan } & Nilai \\
\hline 1 & Nilai tertinggi & 75 \\
\hline 2 & Nilai Terendah & 50 \\
\hline 3 & Nilai Rata-rata & 61 \\
\hline
\end{tabular}

Berdasarkan table diatas menunjukkan bahwa nilai tertinggi adalah 75 , dan nilai terendah adalah 50, sedangkan nilai rata-rata siswa adalah 65 .

\section{Siklus I (Pertama) \\ Perencanaan Tindakan}

Perencanaan yang penulis buat pada siklus I yaitu: 1) menyusun silabus; 2) membuat Rencana Pelaksanaan Pembelajaran (RPP); 3) membuat Lembar Kerja Siswa (LKS); 4) membuat instrmen soal; 5) membuat lembar observasi dan 6) memilih bahan ajar yang sesuai.

\section{Pelaksanaan Tindakan}

Pada pelaksanaan kegiatan ini, penulis melakukannya sesuai dengan standar proses (PerMendiknas No.14/2007), disamping itu penulis juga sudah mendesain atau merancang pembelajaran ini dengan menggunakan metode demonstrasi. Langkah-langkah pembelajaran yang dilakukan adalah: kegiatan pendahuluan, kegiatan inti dan kegiatan penutup.

\section{Observasi}

Pelaksanaaan observasi dilakukan oleh teman sejawat selaku pengamat terhadap pelaksanaan pembelajaran yang dilaksanakan oleh penulis dan terhadap aktifitas siswa didalam mengikuti proses pembelajaran. Pada pertemuan menunjukkan bahwa pelaksanaan pembelajaran sudah sesuai dengan skenario atau rencana, akan tetapi ada beberapa hal yang perlu diperbaiki antara lain : 1) Guru belum maksimal membimbing siswa dalam membuat kesimpulan; 2) Guru masih kurang dalam memberi motivasi bagi siswa; 3) Guru melakukan penilaian belum maksimal; 4) Pengelolaan waktu belum efektif; 5) Dalam memberikan penguatan guru masih kurang; 6) Dalam menerapkan role playing dalam pembelajaran Bahasa Inggris belum optimal sehingga kelas tidak dapat terkontrol. Berikut adalah hasil belajar siswa pada siklus 1. 
Tabel 4. Rekapan Hasil Belajar Siswa Siklus

\begin{tabular}{|c|c|c|c|c|c|}
\hline No & Hasil (angka) & Hasil (hurup) & Arti Lambang & Jumlah Siswa & Persentase (\%) \\
\hline 1 & $86-100$ & A & Sangat baik & 0 & 0 \\
\hline 2 & $71-85$ & B & Baik & 6 & 19 \\
\hline 3 & $56-70$ & C & Cukup & 19 & 61 \\
\hline 4 & $41-55$ & D & Kurang & 6 & 19 \\
\hline 5 & $<40$ & E & Sangat kurang & 0 & 0 \\
\hline \multicolumn{7}{|c|}{ Jumlah } & 31 & $100 \%$ \\
\hline
\end{tabular}

Berdasarkan tabel menunjukkan bahwa yang jumlah yang mendapat nilai sangat baik (86-100) adalah tidak ada (0\%), yang mendapat nilai baik (75-85) berjumlah 6orang (19\%), yang mendapat nilai cukup (56-70) berjumlah 19 orang (61\%), yang mendapat nilai kurang (41-55) berjumlah 6 orang (19\%) dan siswa yang mendapat nilai sangat kurang $(<40)$ tidak ada $(0 \%)$.

Tabel 5. Ketuntasan Belajar Siswa Siklus I

\begin{tabular}{|c|l|c|c|}
\hline \multirow{2}{*}{ No } & \multirow{2}{*}{ Ketuntasan } & \multicolumn{2}{|c|}{ KKM 68 } \\
\cline { 3 - 4 } & & Jumlah & Persentase (\%) \\
\hline 1 & Tuntas & 15 & 48 \\
\hline 2 & Tidak tuntas & 16 & 52 \\
\hline \multicolumn{2}{|c|}{ Jumlah } & 31 & 100 \\
\hline
\end{tabular}

Berdasarkan tabel di atas dapat dijelaskan bahwa persentase ketuntasan belajar siswa sudah mulai meningkat yaitu siswa yang tuntas belajar menjadi 15 siswa (48\%) dari 31 jumlah siswa keseluruhan sedangkan yang tidak tuntas berjumlah 16 siswa (52\%).

Tabel 6. Rata-rata Hasil Tes siklus I

\begin{tabular}{|l|l|c|}
\hline No & \multicolumn{1}{|c|}{ Keterangan } & Nilai \\
\hline 1 & Nilai tertinggi & 80 \\
\hline 2 & Nilai Terendah & 50 \\
\hline 3 & Nilai Rata-rata & 65 \\
\hline
\end{tabular}

Berdasarkan table diatas menunjukkan bahwa nilai tertinggi adalah 80, dan nilai terendah adalah 50, sedangkan nilai rata-rata siswa adalah 65.

\section{Refleksi}

Guru peneliti bersama dengan guru kolaborasi membahas tindakan yang harus diperbaiki dan tindakan yang dipertahankan pada proses belajar mengajar siklus II. Pada dasarnya pembelajaran yang dilakukan oleh sudah berada diangka cukup dan masih harus ditingkatkan lagi dengan: 1) memotivasi siswa agar lebih lagi aktif belajar; 2) membimbing siswa mengerjakan tugas; 3) membimbing siswa membuat kesimpulan; 4) 
Mariani

memberikan penguatan diakhir pembelajaran; 5) Penguasaan metode pembelajaran harus ditingkatkan lagi.

\section{Siklus II (Kedua)}

\section{Perencanaan Tindakan}

Perencanaan yang penulis buat pada siklus II yaitu:1) menyusun silabus; 2) membuat RPP; 3) membuat LKS, 4) membuat instrmen soal; 5) membuat lembar obsevasi; dan 6) memilih bahan ajar yang sesuai.

\section{Pelaksanaan Tindakan}

Berikut langkah-langkah pembelajaran yang dilakukan: kegiatan pendahuluan, kegiatan inti dan kegiatan penutup.

\section{Observasi}

Pelaksanaaan observasi dilakukan oleh teman sejawat selaku pengamat terhadap pelaksanaan pembelajaran yang dilaksanakan oleh penulis dan terhadap aktifitas siswa didalam mengikuti proses pembelajaran. Pada pertemuan menunjukkan bahwa pelaksanaan pembelajaran sudah sesuai dengan skenario atau rencana, akan tetapi ada beberapa hal yang perlu diperbaiki antara lain: 1) Guru dalam menyampaikan tujuan pembelajaran harus dilakukan dengan lebih jelas kepada siswa. 2) Membimbing siswa membuat kesimpulan; 3) Memotivasi siswa yang tidak aktif dalam proses belajar mengajar dengan cara mendekati tempat duduk siswa untuk melihat aktivitas siswa lebih dekat; 4) Guru harus lebih aktif membimbing siswa dalam mengerjakan tugas; 5) Tindakan yang direncanakan dapat dilaksanakan tetapi belum maksimal. Berikut hasil belajar siswa pada pertemuan I Siklus II.

Tabel 7. Rekapan Hasil Belajar Siswa Siklus II

\begin{tabular}{|c|c|c|c|c|c|}
\hline No & Hasil (angka) & $\begin{array}{c}\text { Hasil } \\
\text { (huruf) }\end{array}$ & Arti Lambang & Jumlah Siswa & Persentase (\%) \\
\hline 1 & $86-100$ & A & Sangat baik & 7 & 23 \\
\hline 2 & $71-85$ & B & Baik & 6 & 19 \\
\hline 3 & $56-70$ & C & Cukup & 18 & 58 \\
\hline 4 & $41-55$ & D & Kurang & 0 & 0 \\
\hline 5 & $<40$ & E & Sangat kurang & 0 & 0 \\
\hline \multicolumn{7}{|c|}{ Jumlah } & 31 & $100 \%$ \\
\hline
\end{tabular}

Berdasarkan tabel menunjukkan bahwa yang jumlah yang mendapat nilai sangat baik (86-100) berjumlah 7 orang (23\%), yang mendapat nilai baik (75-85) berjumlah 6 orang (19\%), yang mendapat nilai cukup (56-70) berjumlah 18 orang (58\%), yang mendapat nilai kurang (41-55) tidak ada lagi $(0 \%)$ dan siswa yang mendapat nilai sangat kurang $(<40)$ tidak ada $(0 \%)$. 
Tabel 8. Ketuntasan Belajar Siswa Siklus II

\begin{tabular}{|c|l|c|c|}
\hline \multirow{2}{*}{ No } & \multirow{2}{*}{ Ketuntasan } & \multicolumn{2}{|c|}{ KKM 68 } \\
\cline { 3 - 4 } & & Jumlah & Persentase (\%) \\
\hline 1 & Tuntas & 24 & 77 \\
\hline 2 & Tidak tuntas & 7 & 23 \\
\hline \multicolumn{2}{|c|}{ Jumlah } & 31 & 100 \\
\hline
\end{tabular}

Berdasarkan table di atas dapat dijelaskan bahwa persentase ketuntasan belajar siswa sudah mulai meningkat yaitu siswa yang tuntas belajar meningkat menjadi 24 siswa (77\%) dari 31 jumlah siswa keseluruhan sedangkan yang tidak tuntas berjumlah 7 siswa $(23 \%)$

Tabel 9. Rata-rata Hasil Tes siklus II

\begin{tabular}{|l|l|c|}
\hline No & \multicolumn{1}{|c|}{ Keterangan } & Nilai \\
\hline 1 & Nilai tertinggi & 90 \\
\hline 2 & Nilai Terendah & 60 \\
\hline 3 & Nilai Rata-rata & 75 \\
\hline
\end{tabular}

Berdasarkan table diatas menunjukkan bahwa nilai tertinggi adalah 90, dan nilai terendah adalah 60, sedangkan nilai rata-rata siswa adalah 75 .

\section{Refleksi}

Setelah siklus II selesai dilaksanakan beserta penilaian terhadap hasil belajar siswa, diketahui bahwa pada dasarnya pembelajaran yang dilakukan oleh guru sudah baik, semua aspek PBM yang dilakukan oleh guru sudah maksimal. Terlihat dari perubahan sikap siswa kerah yang positif dari tidak memperhatikan guru menjadi memperhatikan guru, dari suka menggangu teman menjadi tidak. Siswa juga sangat semangat ketika disuruh dalam praktek membaca yang lebih di fokus dalam melakukan praktek membaca teks narative. Hal ini merupakan hasil dari penerapan metode role playing, selain itu terjadi peningkatan juga pada hasil belajar siswa yaitu ketuntasan belajar siswa meningkat dari $48 \%$ (siklus I) menjadi $77 \%$ Berarti terjadi peningkatan sebesar $29 \%$ dari siklus I.

\section{PENUTUP}

\section{Simpulan}

Metode Role Playing adalah suatu cara penguasaan bahan-bahan pelajaran melalui pengembangan imajinasi dan penghayatan siswa sehingga dalam penggunaan metode ini akan lebih cepat ditangkap oleh siswa.

1. Dengan penggunaan metode role playing bisa menjadi salah satu acuan guru untuk meningkatkan hasil belajar siswa pada mata pelajaran Bahasa Inggris khususnya dalam materi teks narative

2. Dengan menggunakan metode role playing dapat meningkatkan ketuntasan belajar siswa sebanyak $42 \%$ yaitu dari kondisi awal 35\% (hasil tes pra siklus) menjadi $77 \%$ (hasil tes siklus terakhir) 
Mariani

\section{DAFTAR PUSTAKA}

Amato. P.R. 2003. Making It Happen From Interactive to Parricipatory Language Teaching: Theory and Practice. USA: Longman.

Darjowidjojo, Soenjono. 2003. Psikolinguistik: Pengantar Pemahaman Bahasa Manusia. Jakarta: Yayasan Obor Indonesia.

Harmer, Jeremy. (2007). The Practice of English Language Teaching (4th ed). New York: Pearson Longman.

Krisdalaksana, Harimurti. 2008. Kamus Linguistik. Edisi Keempat. Jakarta: Gramedia Pustaka Utama

Wibowo, Wahyu. 2001. Manajemen Bahasa. Jakarta: Gramedia Pustaka Utama

Sabri, Ahmad. 2005. Strategi Belajar Mengajar Micro Teaching. Jakarta: PT. Ciputat Press.

Komalasari, Kokom. 2011. Pembelajaran Kontekstual. Bandung: Refika Aditama. 